\title{
Penerapan Pembelajaran Matematika Realistik Pada Penjumlahan Pecahan Guna Meningkatkan Hasil Belajar Siswa Kelas V SDN 28 Kota Parepare
}

\author{
Yonathan Saba' Pasinggi ${ }^{1}$, Ritha Tuken ${ }^{2}$ \\ ${ }^{1,2}$ Progam Studi PGSD Fakultas Ilmu Pendidikan Universitas Negeri Makassar \\ 1yonathan.s.pasinggi@unm.ac.id \\ 2ritha.tuken@unm.ac.id
}

\begin{abstract}
ABSTRAK
Penelitian ini bertujuan untuk mengetahui penggunaan pendekatan PMRI (Pembelajaran Matematika Realistik Indonesia) pada pembelajaran matematika dapat meningkatkan pemahaman penjumlahan pecahan pada siswa kelas V SDN28 Kota Parepare. Penelitian ini menggunakan pendekatan kualitiatif, jenis penelitian yaitu penelitian tindakan kelas yang berlokasi di SDN 28 Kota Parepare. Pemilihan lokasi ini berdasarkan pertimbangan peneliti melihat penerapan pendekatan pembelajaran matematika realistik di sekolah dasar belum diterapkan. Prosedur Penelitian PTK yaitu (1) Perrencanaan, (2) Pelaksanaan, (3) observasi, (4) refleksi. Teknik pengumpulan data yang digunakan dalam penelitian ini meliputi (1) observasi, (2) dokumentasi, (3) wawancara, (4) tes. Analisis data merupakan upaya meningkatkan hasil belajar mahasiswa dengan penerapan pendekatan matematika realistik. Hasil penelitian pada tes awal menunjukan bahwa kemampuan mahasiswa memahami materi pelajaran masih dalam kategori kurang, setelah dilakukan pembelajaran menunjukkan peningkatan yang signifikan dengan hasil evaluasi pada siklus I berada pada kualifikasi baik (B), penelitian dilanjutkan pada siklus ke II karena peneliti belum puas dengan hasil yang diperoleh pada siklus I, hasil evaluasi pada siklus II menunjukkan peningkatan yang signifikan hasilnya pada kategori sangat baik. Hal ini menunjukkan bahawa penerapan pendekatan matematika realistik dapat meningkatkan hasil belajar mahasiswa di SDN 28 Kota Parepare.
\end{abstract}

Kata kunci: pembelajaran matematika realistik

\section{PENDAHULUAN}

Pemerintah mempunyai peran penting untuk perbaikan kurikulum, sebab kurikulum merupakan alat untuk peningkatan mutu pendidikan. Upaya yang dilakukan oleh pemerintahadalah melalui penelitian. Pada penelitian ini mengkaji mata pelajaran metematika . Sebab mata pelajaran matematika digunakan dalam berbagai aspek disiplin ilmu untuk memajukan pola pikir manusia.

Matematika merupakan mata pelajaran yang dapat digunakan untuk membentuk kepribadian siswa, sesab matematika merupakan mata pelajaran yang bernalar, serta melalui penalaran dapat mengembangkan keterampilan siswa, Belajar metematika dapat membentuk pola piker yang logis serta mempunyai peranan penting untuk meningkatan kualitas sumber daya manusia. Apabila menguasai matematika dapat membantu pola pikir yang ampuh dalam mempelajari mata pelajaran lain pada setiap jenjang pendidikan.
Menurut gusti (2001) matematika realisik merupakan teori pembelajaran yang bertitik tolak dari hal - hal yang nyata bagi siswa dan penekankanya melalui kerja kelompok, sehingga siswa dapat mengemukakan pendapatnya dengan teman sekelasnya dan pada akhirnya siswa dapat menemukan jawabanya sendiri melalui kerja secara individual maupun kelompok.

Fauzi (2002) menyatakan bahwa pendekatan pembelajaran matematika realistik pada penjumlahan pecahan yang penekanannya pada aktivitas siswa dalam mencapai tujuan pembelajaran melalui lima tahap yaitu (1) tahap memahami masalah kontestual, (2) tahap menjelaskan masalah kontestual (3) tahap menyelesaikan masalah, (4) tahap membandingkan jawaban / mendiskusikan jawaban, dan (5) tahap menyimpulkan

Pada pendekatan matematika realistik, aktivitas belajarnya dipandang sebagai suatu stimulus atau rangsangan kepada siswa dalam melaksanakan proses pembelajaran. Pada pendekatan ini sebagai fasilitator adalah guru 
yang berperanan untuk membimbing dalam pembelajaran yang demokratis, sehingga siswa lebih aktif dalam melaksanakan tugasnya dalam bentuk kelompok atau individu sehingga masalah yang dibririkan dapat diselesaikan dengan bimbingan guru.

Pendekatan PMRI (Pendidikan Matematika Realistik Indonesia) merupakan operasionalisasi dari pendekatan matematika berkembang di Belanda dengan nama Realistic Mathematices educattion (RME) yang artinya pendidikan matematika realistik. Menurut Soedjadi (2002:2) menyatakan PMRI merupakan model pembelajaran matematika yang dikembangkan di Indonesia dengan penekamannya pada lingkungan sekitar siswa sebagai objek pembelajaran matematika. Sedangkan Freuendenthal dalam Fausan (2004: 5) mengemukakan bahwa pembelajaran matematika realistik merupakan suatu pendekatan pembelajaran matematika dimana matematika dipandang sebagai suatu kegiatan yang dilakukan oleh manusia.

Berdasarkan dari pendapat di atas, dapat disimpulkan bahwa pembelajaran matematika realistik merupakan suatu teori dalam pendidikan matematika yang bertumpuh pada ide sebab matematika merupakan suatu aktivitas yang dilakukan oleh manusia, dan matematika dapat dikaitkan dengan dunia nyata melalui kehidupan sehari-hari.

Pembelajaran matematika realistik pada dasarnya penekanannya pada realitas dunia nyata dan lingkungan sekitar sehingga siswa lebih muda memahami konsep matematika melalui proses pembelajaran. Tujuan pendidikan matematika dapat tercapai dengan lebih baik apabila pembelajarannya diaplikasikan dengan dunia nyata. Realita atau sesuatu yang nyata, kongkrit yang dapat diotak atik oleh siswa melalui perantaraan benda kongkrit, sedangkan lingkungan sekitar dijadikan objek belajar siswa yang ada kaitannya dengan mata pelajaran matematika sesuai dengan kehidupan sehari-hari.

Penelitian ini penekanannya pada pembelajaran matematika tentang penjumlahan pecahan. Kata pecahan (fraction) diartikan berbeda-beda. Ada yang mengartikan bilangan rasional, lambang bilangan untuk bilangan rasional. Sedangkan menurut Kamus Besar Bahasa Indonesia pecahan berarti bilangan yang bukan bilangan bulat. Beberapa definisi para ahli tentang pengertian pecahan sebagai berikut :
a. Kennedy and Tipps dalam Masniladevi,( 2003: 37) menyatakan

pecahan di Sekolah Dasar adalah sebagai suatu bilangan dari himpunan bilangan rasional yang dapat dinyatakan dalam bentuk $\frac{a}{b}$, dimana a sembarang bilangan cacah dan $b$ sembarang bilangan cacah bukan nol.

b. Untoro (2006: 95) menyatakan suatu bilangan yang merupakan hasil bagi antara bilangan bulat dan bilangan asli dimana bilangan yang dibagi atau pembilang nilainya lebih kecil dari bilangan pembaginyaatau penyebutnya.

c. Soewito, dkk (1993: 152) menyatakan pecahan adalah bilangan yang lambangnya terdiri dari pasangan berurutan bilangan bulat $a$ dan $b$ (dengan $b \neq 0$ ) yang merupakan penyelesaian persamaan $b x=a$, ditulis $\frac{a}{b}$ atau $a: b$.

d. Darhim, dkk (1991: 163) menyatakan pecahan adalah bilangan yang dapat ditulis dalam bentuk $\frac{a}{b}$ dimana a dan b bilangan bulat dan $b \neq 0$ pada pecahan $\frac{a}{b}$, a disebut pembilang dan $\mathrm{b}$ disebut penyebut pecahan tersebut.

Dari beberapa depenisi pecahan di atas, maka di Sekolah Dasar pengertian pecahan dikaitkan dengan suatu yang utuh dibagi menjadi bagian-bagian yang sama, dan memperhatikan bagian tertentu.

Pembelajaran penjumlahan pecahan melalui pendekatan Pembelajaran matematika realistik, pembelajarannya dimulai dari penjumlahan bilangan bulat, kemudian dilanjutkan dengan konsep penjumlahan pecahan melalui pendekatan matematika realistik, dengan memanfaatkan benda konkrit yang utuh dantidak utuh sehingga siswa dapat memahami penjumlahan pecahan. Melalui pembelajaran ini siswa dapat memahami bahwa pecahan merupakan bagian dari keseluruhan yang utuh. Untuk lebih memahami penjumlahan pecahan siswa diharapkan terlibat lansung dalam proses pembelajaran melalui benda kongkrit sehingga siswa dapat menemukan jawabanya sendiri sehingga dapat mengkonstruksi konsep tersebut pada pikirannya. Kegiatan pembelajaran yang memanfaatkan dunia nyata melalui benda-benda kongkrit dengan mudah siswa memahami sebab langsusng mengotak 
atik benda kongkrit tersebut melalui bimbingan guru.

\section{METODE PENELITIAN}

Pendekatan Penelitian yang adalah pendekatan kualitiatif dan jenis penelitian yaitu penelitian tindakan kelas.Tempat pelaksanaan penelitian ini adalah SDN No. 28 Kota Parepare pada semester genap tahun pelajaran 2010/2011 dengan penekanannya pada perbaikan pembelajaran penjumlahan pecahan adalah Siswa Kelas V. semester genap.

Data yang digunakan berupa data proses melalui observasi, catatan lapangan, dan hasil belajar berupa tes. Observasi digunakan untuk aktivitas guru dalam pembelajaran dengan pendekatan matematika realsistik serta aktivitas siswa dalam mengikuti proses pembelajaran. Selanjutnya tes digunakan untuk penguasan siswa dalam menentukan hasil belajar.

Tehnik pengumpulan yang digunakan antara lain. mengumpulkan, menyeleksi, menilai, menyimpulkan dan menentukan data. Tehnik yang paling tepat untuk penelitian kualitatif adalah observasi, wawancara, catatan lapangan, dan dokumentasi. Ke empat tersebut digunakan secara profesional dan mengarah pada sasaran yang diharapkan.

a. Tehnik Observasi

Teknik ini dilakukan untuk mengamati dan mencatat kondisi yang terjadi selama pembelajaran berlangsung.

b. Teknik wawancara

Wawancara dilakukan untuk mengetahui secara mendalam tingkat penguasaan siswa dalam menyelesaikan soal penjumlahan pecahan

c. Teknik catatan lapangan

Teknik catatan lapangan digunakan sebagai catatan refleksi peneliti terhadap pelaksanaan berupa kelemahan, kesalahan tindakan pada saat pembelajaran berlangsung dengan penekanannya pada aktivitas guru dan siswa dalam pembelajaran.

d. Teknik dokumentasi

Teknik ini digunakan untuk melengkapi data serta teori yang relevan mengenai kamampuan siswa dalam menyelesaikan soal penjumlahan pecahan dalam pembelajaran matematika di Kelas V SDN No. 28 Kota Parepare.

\section{HASIL \& PEMBAHASAN}

Hasil pelaksanaan pada siklus I, mengenai penjumlahan pecahan penyebut sama penguasaan hasil belajar siswa sudah mencapai ketuntasan belajar, sedangkan penguasaan penjumlahan pecahan yang penyebutnya tidak sama belum tuntas sehinga pembelajaran dilanjutkan pada siklus ke II dengan penekanannya pada penjumlahan pecahan yang penyebutnya tdk sama dengan menyamakan penyebut. Pada pembelajaran siklus I penguasaan hasi belajar siswa pada penjumlahan pecahan dengan penyebut sama telah tercapai. Sedangkan untuk data proses menurut pengamat ( observer ) yang dikerjakan oleh guru kelas menyatakan bahwa ada beberapa langkah pendekatan yang belum terlaksana oleh peneliti, yakni peneliti tidak menyebutkan tujuan pembelajaran, tidak memberikan persepsi, kurangnya motivasi kepada siswa dan masih ada beberapa hal yang lainnya.

Untuk lebih jelasnya kegagalan dan keberhasilan yang terjadi pada siklus I ini adalah :

1) Masih ada kelompok yang tugasnya belum tuntas sesuai dengan waktu yang telah ditentukan, penyebabnya masih ada anggota kelompok tidak pokus pada proses pembelajaran.

2) Langkah-langkah pendekatan pada proses pembelajaran belum efektif, sebab siswa dalam melakukan diskusibelum kompak.

3) Motivasi dan apersepsi dari peneliti belum mampak pada siswa.

4) Bimbingan yang dilakukan oeleh peneliti pada siswa belum maksimal, sebab siswa mengalami kesulitan dalam belajar.

5) Penguasaan siswa setelah tindakan dilakukan mengalami peningkatan dibandingkan sebelum sebelum masuk pada siklus I .

6) sebagian siswa mulai mengerjakan tugasnya yang hampir tuntas.

Dari pelaksanaan tindakan siklus I di atas terlihat bahwa peneliti dalam proses pembelajaran belum tuntas begitu pula hasil belajar siswa dalam menjumlahkan pecahan dianggap belum berhasil, maka peneliti melanjutkan pada siklus II. Pembelajaran pada siklus II dikatakan berhasil kerana pembelajaran penjulahan pecahan peneliti memperhatikan kelemahan pada siklus I proses dan hasil belajar siswa melalui pendekatan matematika realistik sudah tercapai. Pada tahap ini, peneliti dan teman sejawat mengamati dan mengevaluasi hasil belajar 
siswa pada akhir pembelajaran maupun pada saat proses belajar mengajar berlangsung. Semua yang didapatkan pada perencanaan , pelaksanaan, observasi dan merefleksi sehingga terlaksana dengan baiksebab peneliti telah memperhatikan kelemahan pada pembelajaran sebelumnya. Oleh karena pembelajaran sudah mencapai kategori baik maka penelitian menghentikan pembelajran pada siklus II karena dianggap cukup karena nilai hasil belajar yang diperoleh siswa sudah melampauhi KKM.

Berdasarkan paparan data pada pelaksanaan penelitian ini, maka pembahasan hasil penelitian setiap siklus dan temuan penelitian pada setiap tindakan sebagai berikut : 1. Siklus I

Pada siklus I Penerapan PMRI (Pembelajaran Matematika Realistik Indonesia) belum terlaksana dengan baik sebab peneliti masih mengalami kesulitan pada saat pembelajaran penjumlahan pecahan sebab langkah-langkah pendekatan matematika reslistik tidak perhatikan. Pelaksanaan melalui benda kongkret sudah berjalan dengan lancar dan siswa mulai memahaminya. Namun masih ada siswa yang belum memahami cara soal menyelesaikan disebabkan penjelasan guru (peneliti) belum maksimal. Penguasaan kelas belum dikuasai sepenuhnya oleh guru sehingga keterlibatan siswa pada proses tidak berjalan sebagai mana mestinya, serta guru jarang memotivasi siswa dalam memahami konsep penjumlahan pecahan yang diberikan.

Dari uraian tersebut di atas peneliti menyimpulkan bahwa bahwa hasil belajar siswa pada penjumlahan pecahan belum terlaksana dengan baik terlihat nilai ketuntasan siswa pada siklus I baru mencapai 73,75\%. Hasil belajarnya berada pada kualifikasi baik (B). Meskipun hasil belajar siswa sedikit mengalami kemajuan tetapi pendekatan Pembelajaran Matematika Realistik.belum maksimal dari hasil yang dicapai oleh siswa sudah tergolong baik, namun peneliti melanjutkan pada siklus II karena masih mengalami kendala pada pelaksanaan pendekatan matematika realistik.

\section{Siklus II}

Bertitik tolah dari kelemahan pada siklus I maka pembelajaran pada siklus II pada pembelajarannya menggunakan benda kongkrit melalui contoh soal penjumlahan pecahan sehingga siswa dengan mudah memahaminya serta perhatian guru kepada siswa berjalan dengan lancar sehingga siswa lebih aktif dalam proses pembelajaran tujuan pembelajaran dapat tercapai, untuk memahami penjumlahan pecahan peneliti memanfaatkan alat peraga benda kongkrit melalui kerja kelompok. Setiap kelompok menyelesaikan soal penjulahan pecahan dengan perantaraan benda kongkrit dengan cepat, hasil belajar siswa dalam menyelesaian penj umlahan pecahan mengalami peningkatan. Tahapan Pendekatan Pembelajaran Matematika Relistik dilakukan dalam penelitian ini antara lain:

a. Tahap pemahaman

1) Membimbing siswa dalam memahami soal yang berbentuk pecahan maupun soal yang berbentuk cerita.

2) Mengarahkan siswa yang belum memahami apabila ada bertanya mengalami kesulitan dalan penyelesaian soal .

b. Tahap penyelesaian masalah

1) Membimbing siswa menentukan KPK untuk menyelesaikan soal.

2) Mengarahkan siswa dalam menyelesaikan soal penjumlahan pecahan dengan menggunakan alat peraga.

c. Tahap membandingkan jawaban

1) Membimbing siswa tampil kedepan mempresentasekan hasil kerja dipapan tulis.

2) Mengarahkan siswa dalam menanggapi hasil kerja temannya

d. Menyimpulkan

Membimbing siswa untuk menarik kesimpulan terhadap setiap pembelajaran yang telah terlaksana.

Pelaksanaan siklus II berjalan dengan lancar tanpa mengalami kesulitan terlihat dari hasil pencapaian siswa dalam menyelesaiakn penjumlahan pecahan berada pada kualifikasi sangat baik dengan hasil belajarnya mencapai $93,75 \%$. Hasil belajar siswa mulai dari paratindakan sampai pada siklus II terlihat mengalami peningkatan mulai dari pratindakan, siklus I dan siklus II adalah sebagai berikut:

a) Pratindakan mencapai hasil 55, $5 \%$

b) Pelaksanaan siklus I mencapai hasil 73,75\%

c) Pelaksanaan siklus II pencapaian hasil 93,75\%

Peningkatan pada siklus I dan siklus II di atas mengalami peningkatan pada setiap siklus, pencapaian skor hasil belajar siswa sangat meningkat. Dapat disimpulkan bahwa penggunaan Pendekatan Matematika Realistik 
pada penjumlahan pecahan di SDN 28 Kota Parepare, menunjukkan hasil yang memuaskan.

\section{KESIMPULAN \& SARAN}

Berdasarkan permasalahan melalui pelaksanaan seperti yang telah dikemukakan pada uraian sebelumnya, maka dapat ditarik kesimpulan bahwa: 1) guru berupaya meningkatkatkan pemahaman siswa tentang penjumlahan pecahan melalui pendekatan PMRI (Pendidikan matematika realistik Indonesia). Guru (peneliti) telah berhasil menerapkan penggunaan pendekatan pembelajaran matematika realistik. Hal ini ditandai dengan adanya peningkatan pada setiap siklus mulai dari (a) Merumuskan indikator sesuai dengan pendekatan PMRI. (b) Cara memotivasi siswa pada setiap tahapan. (c) Langkah - langkah pelaksanaan pembelajaran disesuaikan dengan penggunaan pembelajaran metematika realistik. (4) memberikan bimbingan kepada sesuai dengan tujuan pembelajaran yang akan dicapai. 2) Melalui penerapan pendekatan PMRI (pendidikan matematika realistik Indonesia), pemahaman siswa terhadap pejumlahan pecahan dapat meningkat. Begitu juga dengan aktifitas kelompok karena dalam pendekatan realistic pembelajarannya dikaitkan dengan realitas siswa.

Dari data di atas, ada beberapa saran yang perlu dan dianggap penting dikemukakan dalam pembahasan pada perbaikan penelitian ini adalah : 1) Guru dalam menerapkan penjumlahan pecahan melalui pendekatan PMRI (pendidikan matematika realistik Indonesia), terbukti telah meningkatkan hasil belajar siswa, harapan peneliti kiranya dapat diikuti oleh guru lainnya pada mata pelajaran yang di anggap cocok dengan pendekatan tersebut. 2) Guru diharapkan menerima kritikan dan saran atas kelemahan-kelemahan dalam proses pembelajaran sebagai hasil refleksi dan bersedia memperbaiki segala kekurangan tersebut, guna meningkatkan hasil belajar terus menerus. 3) Kepala sekolah sebagai penanggung jawab pendidikan di sekolah, kiranya memberikan dorongan dan motivasi langsung serta fasilitas kepada guru lainnya dalam mengembangkan mutu pendidikan di sekolah.

DAFTAR PUSTAKA

Darhim, Sutarno. 1991. Materi pokok Pendidikan matematika 2 untuk PGSD penyetaraan. Jakarta : Depdikbud
Fauzan, Ahmad.2004. Eksperimentasi Pembelajaran Matematika Pada Pokok Bahasan Melalui Pendekatan Realistik Ditinjau Dari Kemampuan Siswa, (Online ) Diakses 05 Oktober 2005.

Fauzi, Amin.2002. Pengembangan Perangkat Pembelajaran Matematika Realistik Pokok Bahasan Pembagian di kelas $V$ $S D$. Surabaya makalah komprehensif PPs UNESA

Gravemeijer,k.1994. Developing Realistic Mathematics Education. Utrecht : Freundenthal Institute.

Hudoyo, Herman. 1993. Pemecahan Masalah Dalam Mengajar Matematika. Jakarta : Depdikbud.

Kurikulum Tingkat Satuan Pendidikan Dasar. 2007. Jakarta : Departemen pendidikan Nasional.

Masniladevi. 2003. Keefektifan Belajar Kooperatif Model STAD (Students Teams-Achienvement Divisioan) Pada Penjumlahan Pecahan Pecahan Di Kelas IV SD Negeri Sumbersari III Kota Malang. Tesis. Malang: Universitas Negeri Malang

Soedjadi.2001. Upaya Guru Dalam Meningkatkan Hasil Belajar Metematika Melalui Pendekatan RME, ( Online ), Diakses 05 Oktober 2005.

Soewito,Sutawidjaja \& karim,1993.Pendidikan matematika I.Jakarta : Depdikbud

Sofyan,G. 1998. Strategi Belajar Mengajar. Kendari: FKIP Unhalu

Suharta, I gusti Putu. 2001. Penerapan pembelajaran Matematika realistik untuk mengembangkan pengertian siswa. Disajikan pada seminar nasional pendidikan matematika realistik di universitas sanata dharma yogyakarta tanggal 14 - 15 november 2001

Undang - Undang Nomor 20 Tahun 2003 tentang Sistem Pendidikan Nasional. 2007. Jakarta : Pustaka Indo Kerjasama Pokja Dikna DPP Partai Golkar.

Untoro,2006. Buku pintar Matematika SD untuk kelas $V$. Jakarta : Wahyu media 